\title{
A Study of Foreign Direct Investment \& Its Impact on Indian Economy
}

\author{
Mukesh Kumar Jain* \\ Faulty of Commerce \& Business Administration, M.M.H. College, Ghaziabad 201001 (U.P.) India \\ Email Id:mkj.1962@gmail.com
}

\begin{abstract}
FDI plays a vital role for economic development of any developing country. The importance of FDI in India has increased significantly over the last two decades. FDI serves as a link between investment and saving. Many developing countries like India, are facing the deficit of savings. This problem can be solved with the help of Foreign Direct Investment. Foreign investment helps in reducing the defect of $B O P$ and provides the base and pre requisite for rapid GDP growth. This study is entirely based on the secondary data. It is based on published annual reports for the period 2004-05 to 2018-19 of NSE, BSE, SEBI, and RBI. We have used Statistical formulas mainly correlation and linear regression analysis has been used to get the result. We conclude that there is significant effect of FDI on India's GDP.

Key Words: FDI, Economic Development, GDP.
\end{abstract}

PAPER/ARTICLE INFO RECEIVED ON: 02/09/2019 ACCEPTED ON: 05/10/2019

Reference to this paper should be made as follows:

Mukesh Kumar Jain (2019), "A Study of Foreign Direct Investment \& Its Impact on Indian Economy", Int. J. of Trade and Commerce-IIARTC, Vol. 8, No. 2, pp. 237-248 
A Study of Foreign Direct Investment \& Its Impact on Indian Economy

Mukesh Kumar Jain

\section{INTRODUCTION}

FDI plays an important role in Indian economic development. FDI is an important and vital component of development strategy in both developed and developing nations and policies are designed in order to stimulate inward flows. In fact, FDI provides a win - win situation to the host and the home countries. Both countries are directly interested in inviting FDI, because they benefit a lot from such type of investment. The 'home' countries want to take the advantage of the vast markets opened by industrial growth. On the other hand, the 'host' countries want to acquire technological and managerial skills and supplement domestic savings and foreign exchange. Moreover, the paucity of all types of resources viz. financial, capital, entrepreneurship, technological know- how, skills and practices, access to markets- abroad- in their economic development, developing nations accepted FDI as a sole visible panacea for all their scarcities. A high level of FDI is viewed as an affirmation country. This is very true in case of various developing countries like India. India is suffering from the scarcity of financial resources and low level of capital formation because it has to majorly depend upon the external sources of Finance. Also the domestic resources are entirely inadequate to carry out development programmes.

\section{LITERATURE REVIEW}

Ahmad \& Ahmad (2014), investigated the role of Foreign Institutional Investors (FIIs) which has become a dynamic force in the development of Indian stock market and is increasingly seen as an important cause of stock market volatility. In order to ascertain the link between the two, present study made a modest attempt to develop an understanding of the FIIs investment and its impact on stock market volatility. The study was conducted using monthly time series on NIFTY, SENSEX and FIIs activity for a period of fifteen years spanning from January, 1999 to December, 2013. To check the non-stationary of the time series the Augmented Dickey-Fuller (ADF) unit root test is applied. In present study, GARCH model was used to study the impact of FIIs capital flows on stock market volatility. From the results of GARCH test analysis, it was inferred that volatility of Indian stock market is influenced by the previous periods volatility and FIIs investment are also contributing significantly to the volatility of NIFTY and SENSEX, which are major indices representing Indian stock market. So results suggest that volatility of Indian stock market and FIIs has increased over the period of study but the volatility was maximum during financial down turn and then normalized to moderated levels.

Bhansali, Vaibhav. (2016), investigated that the liberalization process initiated in India in the early 1990s brought radical changes in the functioning of the Indian stock market. Rising globalization, deregulation, and foreign investments made the Indian stock exchanges competitive and efficient in their functioning being a developing country, India attracts a large sum of FII every year. One of the most dominant investor groups that have emerged to play a critical role in the overall performance of the stock market is Foreign Institutional Investors (FIIs). In this regard, the role of investors is, thus, the key to success of the market-guided economic system and since it is FIIs who pump their savings into the markets, their investments need to be channelized to the most rewarding sectors of the economy. Indian stock market, which is one of the indicators of the economic status, is also affected by the foreign investments made. This portfolio flows by FIIs bring with them a great advantage as they are engines of growth while 
lowering the cost of capital in the emerging market. This paper indicates whether Foreign Institutional investors really have an impact on the stock market of India.

Das, L., and Mahapatra, R. P., (2017), studied the growing participation of Foreign Institutional Investors (FIIs) in Indian stock market has raised eyebrows of many Indians. Their influence on stock markets had been widely debated and remained a hot topic in the media. The FIIs had emerged as noteworthy players and provider of financial services in the Indian stock market whose contribution have added in the growth and development of the stock markets. Author examined whether market movement can be explained by these investors and their impact on the stock markets. FIIs, because of its short-term nature can have bi-directional causation with the returns of other domestic financial markets. Thus, understanding the determinants of FII is very important for any emerging economy as it exerts a larger impact on the domestic financial markets. This paper was an attempt to find out the determinants of FIIs and their existing impact on the Indian Stock Markets and the Indian Economy as a whole.

Jain, V., Nair, K. and Jain, D. (2014), has explained that the progress and prosperity of a nation is reflected by its sustained economic growth and development which is provided by investment. The authors explained that the Foreign Institutional Investors (FIIs) have emerged as important players in the Indian equity market in the recent past and are gradually becoming one of the major players that contribute towards the growth of the financial markets, more so in developing economies like India. The main objective was to study the effect of FII flow on capital markets, extent of Granger Causality between FII flows and capital market growth and lead-lag relationship between FII flows and NSE Nifty. The database used for the study is composed of the monthly data of FII flow and NSE Nifty. The data used was collected from SEBI and major stock exchanges' websites. Findings of stationarity, causality and co integration have been computed with the help of Gretl and other relevant software available for statistical analysis. The results of the study did imply that FII investment and NIFTY were influenced by various other macroeconomic fundamentals on the basis of which growth were studied and in any way did not have any causal relationship with each other.

Kedia, N., (2016) studied the changing global scenario in which foreign institutional investors has affected Indian stock market. FIIs have emerged as very significant players in the Indian stock market and their growing contribution and participation had added as an important aspect for the development of stock markets in India. Indian Stock Markets have reached new heights and became more volatile making the researches work in this dimension of establishing the link between FIIs and Stock Market. The study was conducted using data from BSE Sensex and FII activity over a period spanning from Jan.2003 to Dec 2012. It provided the evidence of significant positive correlation between FII activity and effects on Indian Stock Market. Study revealed that FIIs have an impact on Indian Stock Market where the value of $R$ was 0.609 which signified that the FIIs had almost $60 \%$ positive impact in stock market. It implied that, inflow of FII's lead to a bullish trend in the market or vice-versa. Furthermore, the impact of foreign institutional investors was more on Sensex as study was specific to the Bombay stock exchange.

Mukherjee (2002) examined the various probable determinants of FII and concluded that (1) Foreign investment flows to the Indian markets tend to be caused by return in the domestic equity market; (2) Indian equity market return has an impact on FII flows; (3) performance of the 
A Study of Foreign Direct Investment \& Its Impact on Indian Economy

Mukesh Kumar Jain

Indian equity market are influenced by the FIIs sale and FIIs purchase, (4) FII investors do not consider Indian equity market for the purpose of diversification of their investment; (5) returns from the exchange rate variation and the fundamentals of the economy may have an impact on FII decisions, but such influence do not prove to be strong enough.

Prusty, T., \& Vishwakarma, R., (2014), explained the Foreign Institutional Investors (FIIs) have emerged as important players in the Indian Stock Market in the recent past. This study made an attempt to develop an understanding of the factors influencing FIIs while making investment in Indian stock market along with the relationship between FII investments and stock market. Author found that there is positive association between FII investments and BSE Sensex and showing direct relationship between each other. FIIs have tremendous power to determine \& decide the direction of Indian stock market. Regulation and Trading Efficiencies, New Issuance Attractive Markets, Infrastructure, Outsourcing, Capital expenditure Cycle, Dollar Weakness, Rising Commodity Prices and Consolidation are some factors which were significantly contributed to causes of FII investments in India. There was a positive correlation between stock indices and FIIs.

Shrivastav (2013) found that investments by FIIs and the movements of Sensex are quite closely correlated in India and FIIs wield significant influence on the movement of Sensex. He concluded that FII had high significant impact on the Indian capital market (BSE Sensex and Nifty). They found that BSE CG, BSE CD, and BSE IT showed positive correlation but BSE FMCG showed negative correlation with FII. The degree of relation was low in all the case. It showed low degree of linear relation between FII and other stock index. This implied that their impact on the stock prices varied from sector to sector which was further influenced by the industry to which it belonged to and the different sectors' performance.

Swapna, G. (2018) examined the impact of FIIs on Indian Stock Market with special reference to BSE and NSE index. The data has been taken from various sources such as BSE, NSE, SEBI reports etc. The twelve-year data of BSE and NSE index average is considered for the period i.e., $2005-06$ to 2016 - 17. The investigation has been made by relating FIIs buys, sales and net investment. The relationship coefficient amongst FII and Sensex for the two investigations is emphatically connected. The impact of these variables on BSE and NSE index are studied in this paper. The Average SENSEX and average of NIFTY 50 index for the period of 12 years are taken in the present study. It is evident that real falls in securities exchange were eventual outcomes of withdrawal of cash by FIIs.

\section{OBJectives OF THE STUDY}

1. To analyse the trends of FDI in the $21^{\text {st }}$ Century in India.

2. To analyse the impact of FDI in Indian Economic Development with reference to GDP.

\section{HYPOTHESIS OF THE STUDY}

$\mathbf{H}_{0}$ : There is no significant relationship between FDI inflow and growth of GDP in India.

$\mathbf{H}_{\mathbf{a}}$ : There is significant relationship between FDI inflow and growth of GDP in India.

\section{RESEARCH Methodology}

The primarily aim of this study is to know the impact of Foreign Direct Investment in Indian Economic Development with reference to GDP. Secondary data has been used in this study. 


\section{SAMPLE DESIGN}

The study has been carried out by selecting mainly two factors: FDI Inflow \& Size of GDP.

\section{Data Collection Method}

It is based on published annual reports for the period 2004-05 to 2018-19 of NSE, BSE, SEBI, and RBI. The data have been collected from Bulletins of Reserve Bank of India, Fact sheets of DIPP, Govt. of India also.

\section{STUdy Period}

This study covered a period of 15 years starting from 2004-05 to 2018-19 taking into consideration the availability of data for the choosing study period.

\section{TOOLS AND TECHNIQUES OF DATA ANALYSIS}

Various statistical formulas are used for data analysis. The statistical techniques applied in this study are basically calculation of Growth Rate, Mean, Standard Deviation, Coefficient of Variance and ANOVA Test. Karl Pearson's correlation and linear regression analysis has also been used to get the result.

\section{Data Analysis}

Evaluation of FDI and GDP in India during (2004-05 to 2018-19)

The following table depicts the picture of FDI inflow and its impact on GDP:

Table No. 1: Growth in FDI Inflow and Size of GDP

\begin{tabular}{|c|c|c|c|c|c|}
\hline Years & $\begin{array}{c}\text { FDI Inflow } \\
\text { (in rupees } \\
\text { crore) }\end{array}$ & $\begin{array}{c}\text { Growth rate } \\
\text { of FDI inflow } \\
\text { (\%) }\end{array}$ & $\begin{array}{c}\text { GDP } \\
\text { (in rupees } \\
\text { crore) }\end{array}$ & $\begin{array}{c}\text { Growth } \\
\text { rate of } \\
\text { GDP (\%) }\end{array}$ & $\begin{array}{c}\text { FDI as a } \\
\text { \% of GDP }\end{array}$ \\
\hline $\mathbf{2 0 0 4 - 0 5}$ & 14653 & 45.60 & $31,86,332$ & 7.47 & 0.46 \\
$\mathbf{2 0 0 5 - 0 6}$ & 24584 & 67.77 & $36,32,125$ & 13.99 & 0.68 \\
$\mathbf{2 0 0 6 - 0 7}$ & 56390 & 129.38 & $42,54,629$ & 17.14 & 1.33 \\
$\mathbf{2 0 0 7 - 0 8}$ & 98642 & 74.93 & $48,98,662$ & 15.14 & 2.01 \\
$\mathbf{2 0 0 8 - 0 9}$ & 142829 & 44.80 & $55,14,152$ & 12.56 & 2.59 \\
$\mathbf{2 0 0 9 - 1 0}$ & 123120 & -13.80 & $63,66,407$ & 15.46 & 1.93 \\
$\mathbf{2 0 1 0 - 1 1}$ & 97320 & -20.96 & $76,34,472$ & 19.92 & 1.27 \\
$\mathbf{2 0 1 1 - 1 2}$ & 165146 & 69.69 & $87,36,330$ & 14.43 & 1.89 \\
$\mathbf{2 0 1 2 - 1 3}$ & 121907 & -26.18 & $99,44,013$ & 13.82 & 1.23 \\
$\mathbf{2 0 1 3 - 1 4}$ & 147518 & 21.01 & $1,12,33,522$ & 12.97 & 1.31 \\
$\mathbf{2 0 1 4 - 1 5}$ & 189107 & 28.19 & $1,24,67,959$ & 10.99 & 1.52 \\
$\mathbf{2 0 1 5 - 1 6}$ & 262322 & 38.72 & $1,37,71,874$ & 10.46 & 1.90 \\
$\mathbf{2 0 1 6 - 1 7}$ & 291696 & 11.20 & $1,53,62,386$ & 11.55 & 1.90 \\
$\mathbf{2 0 1 7 - 1 8}$ & 288889 & -0.96 & $1,70,95,005$ & 11.28 & 1.69 \\
$\mathbf{2 0 1 8 - 1 9}$ & 309867 & 7.26 & $1,90,10,164$ & 11.20 & 1.63 \\
\hline
\end{tabular}

Source: compiled $\mathcal{E}$ computed from the various issues of RBI Bulletin, Ministry of Commerce $\mathcal{E}$ http://statisticstimes.com/economy/gdp-of-india.php

The Table No. 1 shows the FDI inflow in India from the year 2004-05 to 2018-19. The table states that India had showed a large amount of FDI inflow. It showed that FDI inflow has been 
A Study of Foreign Direct Investment \& Its Impact on Indian Economy

Mukesh Kumar Jain

increased by more than 21 times during the study period because the FDI Inflow has been increased from Rs. 14653 crore in 2004-05 to Rs. 309867 crore in 2018-19.

The gross domestic product (GDP) measures of national income and output for a given country's economy. The gross domestic product (GDP) is equal to the total expenditures for all final goods and services produced within the country in a stipulated period of time.

The above table also describes the GDP of India from the year 2004-05 to 2018-19. The table states that India had showed a huge growth in term of GDP. It showed that size of Indian Economy based on GDP has been increased by more than 6 times during the study period because the GDP has been increased from Rs. 31,86,332 crore in 2004-05 to Rs. 1,90,10,164 crore in 2018-19.

Due to technological up-gradation, access to global managerial skills and practices, optimal utilization of human and natural resources, making Indian industry internationally competitive, opening up export markets, providing backward forward linkages and access to international quality goods and services the Indian Government has used many steps to attract more FDI. The highest amount of FDI was received in the year 2018-19, amounting to Rs.309867 crore. The highest growth rate of FDI inflow is in the year 2006-07 i.e., 129.36 percent. Hence, the foreign investments have been increasing in India. On the other hand, the highest value of GDP in term of Rupees was in the year 2018-19, amounting Rs. 1,90,10,164 crore. The highest growth rate of GDP was in the year 2008-09 i.e., 2.59 percent. In Brief, FDI has been playing a key role in the growth of Indian Economy in term of GDP.

\section{Future OutLoOK}

India is estimated to become a US\$ 5 trillion economy by the end of 2024-25, Indian economy will require a huge amount to fund infrastructure (roads, airports and ports), defense, space and Communication sector. Therefore, government is in the process of liberalizing FDI norms in these sector especially construction activities and railways, which could bring in investments to meet the target. The government is also relaxing FDI norms in other sectors for foreign investors to invest. FDI in multi-brand retail has been allowed up to 51 per cent. The minimum requirement for the FDI is US\$ 200 million, of which at least 50 per cent must be invested in 'backend infrastructure' within three years following the initiation of the FDI. FDI limit in single-brand retail has been increased to 100 per cent; 49 per cent will be under the automatic route and the rest through the FIPB route.

\section{SOURCES OF FDI IN INDIA}

India has broadened the sources of FDI in the period of reforms. There were 165 countries investing in India in 2018-19 as compared to 132 countries in 2011-12. Thus, the number of countries investing in India increased in $21^{\text {st }}$ Century. After liberalization of economy Mauritius, Singapore, Japan, UAE, Cayman Islands and many more countries predominantly appears on the list of major investors apart from U.S., U.K., Germany, Italy, and France which are not only the major investor now but in $20^{\text {th }}$ century also. 
Table No. 2: Share of Top Ten Investing Countries FDI Equity Inflows IN India

(Financial years 2011-12 to 2018-19)

Amount Rupees in crores (US\$ in million)

\begin{tabular}{|c|c|c|c|c|c|c|c|c|c|c|c|}
\hline \multirow[b]{2}{*}{ Ranks } & \multicolumn{10}{|c|}{ Countries } & \multirow{3}{*}{\begin{tabular}{|l} 
Total \\
FDI \\
Inflo \\
ws \\
From \\
All \\
Coun \\
tries *
\end{tabular}} \\
\hline & 1 & 2 & 3 & 4 & 5 & 6 & 7 & 8 & 9 & 10 & \\
\hline Years & $\begin{array}{l}\text { Maur } \\
\text { itius }\end{array}$ & $\begin{array}{l}\text { Sing } \\
\text { apor } \\
\text { e }\end{array}$ & $\begin{array}{c}\text { Japa } \\
\mathbf{n}\end{array}$ & $\begin{array}{c}\text { Neth } \\
\text { erlan } \\
\text { ds }\end{array}$ & U.K. & $\begin{array}{l}\text { U.S. } \\
\text { A. }\end{array}$ & $\begin{array}{c}\text { Ger } \\
\text { man } \\
y\end{array}$ & $\begin{array}{l}\text { Cyp } \\
\text { rus }\end{array}$ & $\begin{array}{l}\text { U.A } \\
\text {.E. }\end{array}$ & $\begin{array}{l}\text { Fra } \\
\text { nce }\end{array}$ & \\
\hline 2011-12 & $\begin{array}{l}46,710 \\
(9,942)\end{array}$ & $\begin{array}{l}24,712 \\
(5,257)\end{array}$ & $\begin{array}{l}14,089 \\
(2,972)\end{array}$ & $\begin{array}{c}6,698 \\
(1,409)\end{array}$ & $\begin{array}{l}36,428 \\
(7,874)\end{array}$ & $\begin{array}{c}5,347 \\
(1,115)\end{array}$ & $\begin{array}{c}7,452 \\
(1,622)\end{array}$ & $\begin{array}{c}7,722 \\
(1,587)\end{array}$ & $\begin{array}{l}1,728 \\
(353)\end{array}$ & $\begin{array}{l}3,110 \\
(663)\end{array}$ & $\begin{array}{l}165,146 \\
(35,121)\end{array}$ \\
\hline $2012-13$ & $\begin{array}{l}51,654 \\
(9,497)\end{array}$ & $\begin{array}{l}12,594 \\
(2,308)\end{array}$ & $\begin{array}{l}12,243 \\
(2,237)\end{array}$ & $\begin{array}{l}10,054 \\
(1,856)\end{array}$ & $\begin{array}{c}5,797 \\
(1,080)\end{array}$ & $\begin{array}{l}3,033 \\
(557)\end{array}$ & $\begin{array}{l}4,684 \\
(860)\end{array}$ & $\begin{array}{l}2,658 \\
(490)\end{array}$ & $\begin{array}{c}987 \\
(180)\end{array}$ & $\begin{array}{l}3,487 \\
(646)\end{array}$ & $\begin{array}{l}121,907 \\
(22,423)\end{array}$ \\
\hline 2013-14 & $\begin{array}{l}29,360 \\
(4,859)\end{array}$ & $\begin{array}{l}35,625 \\
(5,985)\end{array}$ & $\begin{array}{l}10,550 \\
(1,718)\end{array}$ & $\begin{array}{l}13,920 \\
(2,270)\end{array}$ & $\begin{array}{l}20,426 \\
(3,215)\end{array}$ & $\begin{array}{l}4,807 \\
(806)\end{array}$ & $\begin{array}{c}6,093 \\
(1,038)\end{array}$ & $\begin{array}{l}3,401 \\
(557)\end{array}$ & $\begin{array}{l}1,562 \\
(255)\end{array}$ & $\begin{array}{l}1,842 \\
(305)\end{array}$ & $\begin{array}{l}147,518 \\
(24,299)\end{array}$ \\
\hline 2014-15 & $\begin{array}{l}55,172 \\
(9030)\end{array}$ & $\begin{array}{l}41,350 \\
(6,742)\end{array}$ & $\begin{array}{l}12,752 \\
(2,084)\end{array}$ & $\begin{array}{l}20,960 \\
(3,436)\end{array}$ & $\begin{array}{c}8,769 \\
(1,447)\end{array}$ & $\begin{array}{l}11,150 \\
(1,824)\end{array}$ & $\begin{array}{c}6,904 \\
(1,125)\end{array}$ & $\begin{array}{l}3,634 \\
(598)\end{array}$ & $\begin{array}{l}2,251 \\
(367)\end{array}$ & $\begin{array}{l}3,881 \\
(635)\end{array}$ & $\begin{array}{l}189,107 \\
(30,931)\end{array}$ \\
\hline $2015-16$ & $\begin{array}{l}54,706 \\
(8,355)\end{array}$ & $\begin{array}{c}89,510 \\
(13,692)\end{array}$ & $\begin{array}{l}17,275 \\
(2,614)\end{array}$ & $\begin{array}{l}17,275 \\
(2,643)\end{array}$ & $\begin{array}{l}5,938 \\
(898)\end{array}$ & $\begin{array}{l}27,695 \\
(4,192)\end{array}$ & $\begin{array}{l}6,361 \\
(986)\end{array}$ & $\begin{array}{l}3,317 \\
(508)\end{array}$ & $\begin{array}{l}6,528 \\
(985)\end{array}$ & $\begin{array}{l}3,937 \\
(598)\end{array}$ & $\begin{array}{l}262,322 \\
(40,001)\end{array}$ \\
\hline 2016-17 & $\begin{array}{l}105,587 \\
(15,728)\end{array}$ & $\begin{array}{l}58,376 \\
(8,711)\end{array}$ & $\begin{array}{l}31,588 \\
(4,709)\end{array}$ & $\begin{array}{l}22,633 \\
(3,367)\end{array}$ & $\begin{array}{c}9,953 \\
(1,483)\end{array}$ & $\begin{array}{l}15,957 \\
(2,379)\end{array}$ & $\begin{array}{c}7,175 \\
(1,069)\end{array}$ & $\begin{array}{l}4,050 \\
(604)\end{array}$ & $\begin{array}{l}4,539 \\
(675)\end{array}$ & $\begin{array}{l}4,112 \\
(614)\end{array}$ & $\begin{array}{l}291,696 \\
(43,478)\end{array}$ \\
\hline 2017-18 & $\begin{array}{l}102,492 \\
(15,941)\end{array}$ & $\begin{array}{c}78,542 \\
(12,180)\end{array}$ & $\begin{array}{l}10,371 \\
(1,610)\end{array}$ & $\begin{array}{l}18,048 \\
(2,800)\end{array}$ & $\begin{array}{l}5,473 \\
(847)\end{array}$ & $\begin{array}{l}13,505 \\
(2,095)\end{array}$ & $\begin{array}{c}7,391 \\
(1,146)\end{array}$ & $\begin{array}{l}2,680 \\
(417)\end{array}$ & $\begin{array}{c}6,767 \\
(1,050)\end{array}$ & $\begin{array}{l}3,297 \\
(511)\end{array}$ & $\begin{array}{l}288,889 \\
(44,857)\end{array}$ \\
\hline 2018-19 & $\begin{array}{l}57,139 \\
\mathbf{( 8 , 0 8 4 )}\end{array}$ & $\begin{array}{l}112,362 \\
\mathbf{( 1 6 , 2 2 8 )}\end{array}$ & $\begin{array}{l}20,556 \\
(\mathbf{2}, \mathbf{9 6 5 )}\end{array}$ & $\begin{array}{l}27,036 \\
(3,870)\end{array}$ & $\begin{array}{c}9,352 \\
(\mathbf{1}, \mathbf{3 5 1})\end{array}$ & $\begin{array}{l}22,335 \\
\mathbf{( 3 , 1 3 9 )}\end{array}$ & $\begin{array}{l}6,187 \\
\mathbf{( 8 8 6 )}\end{array}$ & $\begin{array}{l}2,134 \\
(296)\end{array}$ & $\begin{array}{l}6,356 \\
\mathbf{( 8 9 8 )}\end{array}$ & $\begin{array}{l}2,890 \\
(406)\end{array}$ & $\begin{array}{l}309,867 \\
\mathbf{( 4 4 , 3 6 6 )}\end{array}$ \\
\hline $\begin{array}{l}\text { Cumulativ } \\
\text { e Inflows } \\
\text { Since }\end{array}$ & 738,156 & 505,946 & 173,332 & 162,251 & 140,370 & 146,372 & 65,477 & 51,544 & 39310 & 36,825 & $2,378,886$ \\
\hline $\begin{array}{l}\text { (Since } \\
\text { April } \\
\text { 2000) } \\
\text { Total } \\
\text { Inflows }\end{array}$ & $(134,469)$ & $(82,998)$ & $(30,274)$ & $(27,352)$ & $(26,789)$ & $(25,556)$ & $(11,708)$ & $(9,869)$ & $(6,652)$ & $(6,643)$ & $(420,142)$ \\
\hline $\begin{array}{l}\text { (in } \% \text { in } \\
\text { terms } \\
\text { US \$) }\end{array}$ & $32 \%$ & $20 \%$ & $7 \%$ & $7 \%$ & $6 \%$ & $6 \%$ & $3 \%$ & $2 \%$ & $2 \%$ & $2 \%$ & $100 \%$ \\
\hline
\end{tabular}

Source: Compiled \& Computed from the various issues of Economic Survey, RBI Bulletin, Ministry of Commerce

Table No. 2 presents the major investing countries in India during 2011-12 to 2018-19. Mauritius is the largest route of investing in India during this period. FDI inflows from Mauritius constitute about $32 \%$ of the total FDI in India and enjoying the top position on India's FDI map. The Singapore is the second largest investing country in India with a share of $20 \%$. The other major countries investing in India are Japan, Netherland, UK, USA, Germany, UAE, Cyprus and France with $7 \%, 7 \%, 6 \%, 6 \%, 3 \%, 2 \%, 2 \%$, \& $2 \%$ share of total investment through FDI route in India. 
Thus, an analysis of last eight years of FDI inflows shows that only six countries accounted for more than three fourth (78\%) share of the total FDI inflows in India.

India needs enormous amount of financial resources to carry forward the agenda of transformation (i.e. from a planned economy to an open market), to tackle imbalance in BOP, to accelerate the rate of economic growth and have a sustained economic growth.

Table No. 3: Sectors Attracting Highest Equity Inflows:

Amount in Rs. crores (US\$ in million)

\begin{tabular}{|c|c|c|c|c|c|c|c|c|c|c|c|}
\hline \multicolumn{2}{|c|}{ Ranks } & 1 & 2 & 3 & 4 & 5 & 6 & 7 & 8 & 9 & 10 \\
\hline ڤัँ & 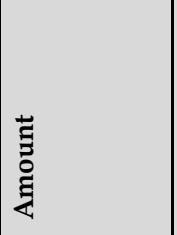 & 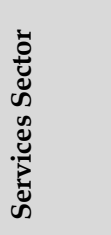 & 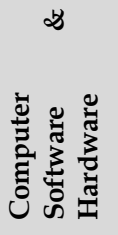 & 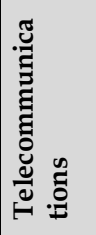 & 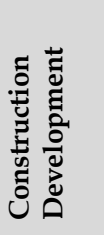 & 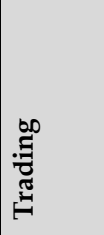 & 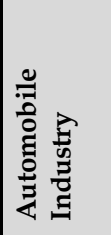 & 选 & 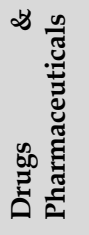 & 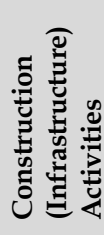 & 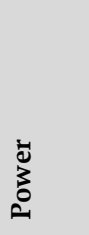 \\
\hline 2011-12 & & 24656 & 3804 & 9012 & 15236 & 2824 & 4347 & 18422 & 14605 & ** & 7678 \\
\hline & & & & 1654 & & & & 1596 & 60 & $* *$ & $292 ?$ \\
\hline & & 294 & & 7987 & & 8191 & 90 & 4738 & 7191 & 2930 & 6519 \\
\hline & Rs. & 27369 & 14162 & 17372 & 4652 & 16755 & 16760 & 4658 & 9052 & 5312 & 4296 \\
\hline & Crore & 45 & 38351 & 8637 & 727 & 25244 & 16437 & 9664 & 4975 & 29842 & 5662 \\
\hline & & 214 & 24605 & 37435 & 703 & 15721 & 108 & 9397 & 5723 & 12478 & 7473 \\
\hline 2017-18 & & 249 & 39670 & 39748 & 3472 & 28078 & 13461 & 8425 & 6502 & 17571 & 1047 \\
\hline & & 639 & 45297 & 18337 & 1503 & 30963 & 183 & 13685 & 1842 & 15927 & 7330 \\
\hline 2018-19 & $\begin{array}{l}\text { (US\$ in } \\
\text { Million) }\end{array}$ & 9158 & 6415 & 2668 & 213 & 4462 & 2623 & 1981 & 266 & 2258 & 1106 \\
\hline Cumulative & $\begin{array}{ll}\text { Rs. } & \text { in } \\
\text { Crore }\end{array}$ & 416301 & 221756 & $\begin{array}{c}18824 \\
9\end{array}$ & 119614 & 143599 & 123989 & 91062 & 84165 & 93873 & 77889 \\
\hline & (US\$ & 74149 & 37238 & 32826 & 25046 & 23021 & 21387 & 16562 & 15983 & 14805 & 14316 \\
\hline $\begin{array}{l}\% \text { age to tota } \\
\text { terms of US\$ }\end{array}$ & $\begin{array}{l}\text { Million) } \\
\text { Inflows (In }\end{array}$ & $18 \%$ & $9 \%$ & $8 \%$ & $6 \%$ & $5 \%$ & $5 \%$ & $4 \%$ & $4 \%$ & $4 \%$ & $3 \%$ \\
\hline
\end{tabular}

Note: (i)** Services sector includes Financial, Banking, Insurance, Non-Financial / Business, Outsourcing, R\&D, Courier, Tech. Testing and Analysis;

(ii) Construction (Infrastructure) Activities (9) included in Construction Development (4) till 2012-13, hence there is no data in that column in 2011-12 and 2012-13; and

(ii) FDI Sectoral data has been revalidated / reconciled in line with the RBI, which reflects minor changes in the FDI figures (increase/decrease) as compared to the earlier published sectoral data.

FDI inflows are welcomed in 63 sectors which are reorganised in 2013-14, in which Construction (Infrastructure) Activities has been separated from Construction Development (Townships, housing, built-up infrastructure and construction-development projects). The above Table No. 3 shows the Service Sector has the highest FDI inflow attracting 18\% share, followed by Computer Software \& Hardware 9\% share and Telecommunications 8\%, Construction Development attracting $6 \%$ share. 


\section{HYPOTHESIS TESTING}

The first model is the simple regression analysis to explain the dependency of GDP on FDI.

$\mathbf{H}_{0}$ : There is no significant relationship between FDI inflow and growth of GDP in India.

$\mathbf{H}_{\mathbf{a}}$ : There is significant relationship between FDI inflow and growth of GDP in India.

Where:

\section{$\mathrm{GDP}=\boldsymbol{\beta} 0+\boldsymbol{\beta} 1$ (FDI)}

In order to fulfil the objectives of the study, Hypothesis has been formulated and further validated through the use of statistical tools like Simple Regression and Correlation analysis. The correlation is applied to study the linear relationship between variables such as FDI \& GDP while, the linear regression analysis is used to evaluate the effects of independent variable (FDI inflows) on a single dependent variable (GDP). Based on the stated sample, the relationship between variables can be explained by simple regression model equation of the form $\mathbf{Y}=\mathbf{a}+\mathbf{b x}$, Where $\mathbf{X}$ will be the independent variable FDI (inflows in India) and $\mathrm{Y}$ will be the dependent variable GDP(in crore).

Table No. 4: Descriptive Statistics

\begin{tabular}{|l|c|c|c|}
\hline & Mean & Std. Deviation & N \\
\hline FDI & 155599.3333 & 95850.72010 & 15 \\
GDP & 9540535.4667 & 5109378.92563 & 15 \\
\hline
\end{tabular}

Table No. 4 shows that average FDI inflow in India is Rs. 155599 Crore and average size of GDP is Rs. 9540535 Crore during the period of study. Whereas Standard Deviation of FDI is Rs. 95850.72 $\mathrm{Cr}$ and S.D. of GDP is Rs, $5109378.93 \mathrm{Cr}$ during the same period.

Table No. 5: Pearson Correlations

\begin{tabular}{|c|c|c|}
\hline & FDI & GDP \\
\hline FDI & 1.000 & 1.000 \\
\hline GDP & .948 & 1.00 p \\
\hline
\end{tabular}

Pearson correlation coefficient, is 0.948 which shows the high degree of positive correlation between FDI and GDP (IN Rupees crore), in India is very direct and strong as the coefficient is between 0 and 1 .

Table No. 6: Regression Coefficients ${ }^{a}$

\begin{tabular}{|c|c|c|c|c|c|c|}
\hline \multirow{2}{*}{\multicolumn{2}{|c|}{ Model }} & \multicolumn{2}{|c|}{$\begin{array}{c}\text { Unstandardized } \\
\text { Coefficients }\end{array}$} & \multirow{2}{*}{$\begin{array}{c}\text { Standardized } \\
\text { Coefficients }\end{array}$} & \multirow[t]{2}{*}{$\mathbf{t}$} & \multirow[t]{2}{*}{ Sig. } \\
\hline & & B & SE & & & \\
\hline 1 & $\begin{array}{l}\text { (Constant) } \\
\text { FDI }\end{array}$ & $\begin{array}{c}-14049.355 \\
.018\end{array}$ & $\begin{array}{c}17809.146 \\
.002\end{array}$ & .948 & $\begin{array}{c}-.789 \\
10.725\end{array}$ & $\begin{array}{l}.444 \\
.000\end{array}$ \\
\hline
\end{tabular}

a. Dependent Variable: GDP

\section{GDP=.018FDI-14049.355}

- $\quad$ Regression result shows the positive value of $\boldsymbol{\beta 1}(.018)$. It indicates that the unit change in the dependent variable due to the change in the value of pridictor.

- Column "standard error" gives the standard errors (i.e. the estimated standard deviation of least squares estimates. In regression model $s(\boldsymbol{\beta 1})$ is 0.002 and $\boldsymbol{\beta} \mathbf{1} / 2$ is $(.018 / 2=.009)$. 
Hence, s $(\boldsymbol{\beta 1}<\boldsymbol{\beta 1} / 2)$, so we reject the null hypothesis and conclude that estimate is statistically significant.

Table No. 7: ANOVA

\begin{tabular}{|c|l|l|l|l|l|l|}
\hline \multicolumn{2}{|c|}{ Model } & \multicolumn{1}{|c|}{ Sum of Squares } & $\begin{array}{l}\text { d } \\
\text { f }\end{array}$ & Mean Square & F & Sig. \\
\hline 1 & Regression & 115563256693.817 & 1 & 115563256693.817 & 115.034 & $.000^{\mathrm{b}}$ \\
& Residual & 13059790917.517 & 1 & 1004599301.347 & & \\
& & & 3 & & & \\
& Total & 128623047611.333 & 1 & & & \\
\hline
\end{tabular}

a. Dependent Variable: FDI

b. Predictors: (Constant), GDP

Model Summary

\begin{tabular}{|c|c|c|c|c|c|c|c|c|c|}
\hline \multirow[t]{2}{*}{ Model } & \multirow[t]{2}{*}{$\mathbf{R}$} & \multirow[t]{2}{*}{$\mathbf{r}^{2}$} & \multirow{2}{*}{$\begin{array}{l}\text { Adjuste } \\
\mathrm{d} \mathbf{r}^{2}\end{array}$} & \multirow[t]{2}{*}{ S E } & \multicolumn{5}{|c|}{ Change Statistics } \\
\hline & & & & & $\begin{array}{c}\mathbf{r}^{2} \\
\text { Change }\end{array}$ & $\begin{array}{c}F \\
\text { Change }\end{array}$ & $\mathbf{d f ^ { 1 }}$ & $\overline{d f^{2}}$ & $\begin{array}{c}\text { Sig. F } \\
\text { Change }\end{array}$ \\
\hline 1 & $.948^{\mathrm{a}}$ & .898 & .891 & $\begin{array}{c}31695.4 \\
1452\end{array}$ & .898 & 115.034 & 1 & 13 & .000 \\
\hline
\end{tabular}

a. Pedictor: (Constant), GDP

- The correlation co-efficient among the variables is 0.948 which indicates the high degree of positive correlation.

- The co-efficient of determination, $\mathrm{R}^{2}$ is 0.898 . This shows that the variation of the dependent variable (GDP) is explained nearly $90 \%$ by the explanatory variable (FDI).

- Adjusted $\mathrm{R}^{2}$ measure the proportion of the variance in the dependent variable that was explained by the variation in the independent variable. "Adjusted $\mathrm{R}^{2}$ shows $89 \%$ of variance was explained.

Hence we reject the null hypothesis at $5 \%$ level of significance. So the estimated results of the model demonstrate that there is significant relationship between FDI and GDP in India.

\section{CONCLUSION}

On the basis of study it is concluded that there is a significant relationship between FDI Inflow and GDP Size of India. There is an increasing trend in the flows of FDI in study period except 2009-10, 2010-11, 2012-13 and 2017-18. Government should provide better environment for attracting the foreign direct investment. Government should welcome inflow of foreign investment in such a way that it should be convenient and favourable for our economy and enable us to achieve our goal like speedy economic development, removal of poverty, regional imbalance in the development and making our Balance of Payment favourable. So we require an ever increasing and high growth rate of GDP. But study shows that GDP is increasing but growth rate is fluctuating in term of percentage. FDI inflows from Mauritius constitute about $32 \%$ of the total FDI in India and enjoying the top position on India's FDI map. The Singapore is the second largest investing country in India with a share of $20 \%$. The other major countries investing in India are Japan, Netherland, UK, USA, Germany, UAE, Cyprus and France with 7\%, 7\%, 6\%, 6\%, $3 \%, 2 \%, 2 \%, \& 2 \%$ share of total investment through FDI route in India. Thus, an analysis of last

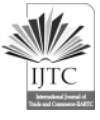


eight years of FDI inflows shows that only six countries accounted for more than three fourth $(78 \%)$ share of the total FDI inflows in India. FDI inflows are welcomed in 63 sectors which are reorganised in 2013-14, in which Construction (Infrastructure) Activities has been separated from Construction Development (Townships, housing, built-up infrastructure and constructiondevelopment projects). Service Sector has the highest FDI inflow attracting $18 \%$ share, followed by Computer Software \& Hardware 9\% share and Telecommunications 8\%, Construction Development attracting $6 \%$ share. In nut shell, the foreign investment has been increasing in India and helping India to develop it on fast track.

\section{REFERENCES}

\section{Articles}

[1]. Ahmad \& Ahmad, (2014), 'Impact of FIIs Investment on Volatility of Indian Stock Market: An Empirical Investigation', Journal of Business \& Economic Policy, ISSN 2375-0766, Vol. 1, No. 2; December, pp. 106-114

[2]. Bhansali, Vaibhav. (2016), 'Impact of FIIs on Indian Stock Market', 10.13140/RG.2.2.35690.36806, https:// www.researchgate.net/publication/330832645

[3]. Das, L., and Mahapatra, R. P., (2017), 'Foreign Institutional Investors and India's Stock Market Behaviour', International Journal of Advanced Research (IJAR) Vol. 5, Issue 10, pp. 1203-1217

[4]. Jain, V., Nair, K. and Jain, D., (2014), Impact of FII Flows on Indian Capital Markets (January 9, 2014). Perspectives on Financial Markets and Systems: Market Efficiency, Behavioural Finance and Financial Inclusion, January. Available at SSRN: https:/ / ssrn.com/abstract $=2707461$

[5]. Kedia, N., (2016), 'Impact of FII's on Indian Stock Market (specific to SENSEX)', International Research Journal of Management Sociology \& Humanity (IRJMSH), Vol. 7, Issue 3, ISSN 2348-9359 (P), pp. 92-109

[6]. Mukherjee (2005), 'Taking Stock of Foreign Institutional Investors.' Economic and Political Weekly. June 11, www.sebi.gov.in.

[7]. Prusty, T., \& Vishwakarma, R., (2014), 'Strategic Insurgence of FIIs in Indian Stock Market', International Journal of Financial Management (IJFM), ISSN(P): 2319-491X; Vol. 3, Issue 1, Mar, pp. 29-38

[8]. Shrivastav, A., (2013), 'A Study of Influence of FII Flows on Indian Stock Market', GYANPRATHA- ACCMAN Journal of Management, Volume 5; Issue 1.

[9]. Swapna, G., (2018), 'Impact of FIIs on Indian Stock Market with special reference to BSE and NSE Index', International Journal of Accounting and Financial Management Research (IJAFMR), ISSN (P): 2249-6882, Vol. 8, Issue 5, Dec., pp. 15-24 
A Study of Foreign Direct Investment \& Its Impact on Indian Economy

Mukesh Kumar Jain

\section{Books}

[1]. Pandey, I.M. "Financial Management", Vikas Publishing House Pvt. Ltd, pp108-157,808939

[2]. Kothari and Garg, (2016), Research Methodology: Method and Techniques, New Age International Publishers, New Delhi, 3rd Ed.

[3]. Prasanna Chandra (IIM B), "Financial Management Theory and Practice”, Second Edition, Tata Mc-Graw Hill Publications, New Delhi, pp- 245-265

\section{Websites}

[1]. http://www.nseindia.com

[2]. http://www.bseindia.com

[3]. http://www.sebi.co.in

[4]. http://www.rbi.co.in

[5]. https://dipp.gov.in/sites/default/files/FDI_Factsheet 